\title{
Hsp70 Genotypes and Heat Tolerance of Commercial and Native Chickens Reared in Hot and Humid Conditions
}

mAuthor(s)

\section{Duangjinda $\mathrm{M}^{\mathrm{l}, \mathrm{I}}$ \\ Tunim $\mathrm{S}^{\prime}$ \\ Duangdaen $\mathrm{C}^{\prime}$ \\ Boonkum W',II}

Department of Animal Science, Faculty of Agriculture, Khon Kaen University, Khon Kaen, 40002, Thailand.

" Research and Development Network Center for Animal Breeding (Native Chickens), Khon Kaen University, Khon Kaen, 40002, Thailand

\section{Mail Address}

Corresponding author e-mail address W. Boonkum

Department of Animal Science, Faculty of Agriculture, Khon Kaen University, Khon

Kaen, 40002, Thailand.

Tel: $\quad+6643202362$

Email: wboonkum@gmail.com

\section{-Keywords}

Heat shock protein, indigenous chicken, HSP70, thermotolerance.

\section{ABSTRACT}

Heat tolerance in poultry production was obtained attention due to the need for genetic lines that can withstand climate changes. This study aimed at investigating heat tolerance in commercial and native broiler genetics, as well as the physiological and growth performance responses of HSP70 genotypes submitted to heat stress. In Experiment I, heterophil:Iymphocyte $(\mathrm{H}: \mathrm{L})$ ratio, as an indicator of heat tolerance, was compared between commercial broilers $(n=100)$ and Thai native chickens ( $n=100)$. Growing chickens (with similar initial weight) of each genetic strain were randomly divided into two groups: 1$)$ thermoneutral environment $\left(26^{\circ} \mathrm{C} \pm 2{ }^{\circ} \mathrm{C}\right)$ and 2$)$ heat stress $\left(36^{\circ} \mathrm{C} \pm 2{ }^{\circ} \mathrm{C}\right)$. The results showed that native chickens originating from a tropical environment presented lower $\mathrm{H}: \mathrm{L}$ ratio and mortality rate compared with commercial broilers. In Experiment II, HSP70 genotypes were compared. PCRRFLP was applied to identify the genotypes ( $C 1 C 1, n=38 ; C 1 C 2, n$ $=38$; and $C 2 C 2, n=28$ ). Ten-week-old chickens of each genotype were evaluated in the same environments described in Experiment I. Heat-stress indicators - respiratory rate (RR), cloacal temperature $(C T)$, packed cell volume (PCV), and average daily gain (ADG) - were measured for three weeks. The significant difference in PCV indicated that C2C2 chickens were less tolerant to heat stress compared to other genotypes. The RR, $C T$, and ADG were not significantly different among all genotypes. Since the C2C2 genotype was shown to be sensitive to heat stress, C1C1 and C1C2 could be used as markers for heat-tolerant genetic strains of Thai indigenous chickens and hybrid commercial lines.

\section{INTRODUCTION}

Heat stress has negative effects on the productivity and welfare of poultry. In the poultry industry, heat stress is responsible for the morbidity and mortality of one million broilers per month (Guerreiro et al., 2004). Several recent reports show that heat stress adversely affects feed intake (Cooper \& Washburn, 1998), water intake (Bruno et al., 2011), growth performance (Altan et al., 2000; Abu-Dieyeh, 2006), blood variables (Altan et al., 2000; Aengwanich, 2007), electrolytes (Borges et al., 2004), and the immune system (Zulkifli et al., 2000b; Mashaly et al., 2004; Tirawattanawanich et al., 2011), increasing mortality (AlFataftah et al., 2007). The optimal temperature range for commercial broilers is about $21-26^{\circ} \mathrm{C}$ (Ewing et al., 1999), and a temperature of 32 ${ }^{\circ} \mathrm{C}$ causes heat stress (Daghir, 1995).

The genetic selection for heat-tolerant broilers is a challenge in global poultry production. In tropical and sub-tropical countries, the evaporative systems applied in broilers houses are not fully functional due to high environmental humidity. In Southeast Asia, crossbreeding between indigenous and exotic breeds is the most popular breeding method of obtaining a commercial hybrid resistant to tropical conditions, 
and capable of producing a reasonable amount of eggs and meat (Mekki et al., 2005; Aengwanich, 2007; Bekele et al., 2010; Kingori et al., 2010). The genetic control of heat tolerance is complex and has low heritability (El-Gendy \& Washburn, 1995). Not all indigenous chickens, and very few exotic breeds, have adequate heat tolerance (Duangduen et al., 2007). The introgression of genes from heat-tolerant lines into grand parental stock is an effective strategy applied to accelerate the genetic progress of commercial lines that can tolerate heat stress. The genes associated with heat tolerance have been investigated in chickens, including the naked-neck (Patra et al., 2002), frizzle (Sharifi et al., 2010), dwarfism (Sharifi et al., 2010), and slow/rapid feathering (Fotsa et al., 2001) genes. In all instances, the genes affected the appearance and some performance parameters of the chickens.

The heat shock protein 70 (HSP70) is a chaperone protein that effectively protects several proteins and cell organelles from stressors (Kiang \& Tsokos, 1998). Changes in HSP70 expression were detected during heat stress in vital organs, such as the heart, liver, and kidneys. The relationship of HSP70 with the survival ability of cells affected by heat stress was extensively investigated by Yu \& Bao (2008). Mazzi et al. (2003); recently reported a nucleotide polymorphism in the coding region of HSP70 in chickens. Duangduen et al. (2007) found that this mutation, although silent, may possibly be used as a heat tolerance marker in indigenous and commercial broiler strains. However, due to the unbalanced number of chickens in each genotype, a lower number of chickens was submitted to heat stress. Hence, this study aimed at comparing the heat tolerance of commercial and indigenous broiler strains, as well as the effects of HSP70 genotypes on the physiological responses and growth performance of those strains under heat stress conditions.

\section{MATERIALS AND METHODS}

Birds were handled and managed according to the Guidelines of Experimental Animal Care of the National Research Council of Thailand (National Research Council of Thailand, 1999). The project was reviewed and approved by KKU - TRF contract number RDG5320010.

\section{Experiment I: Effects of heat stress on commercial and Thai Native chickens}

\section{Bird management and heat stress conditions}

Commercial broilers were compared with native Thai chickens (Gallus domesticus) both under normal and heat stress conditions. A total of 200 chickens with equal numbers of males and females were used in the study. Broiler chickens $(n=100)$ and Thai native chicken $(n=100)$ were obtained from commercial company and fromthe Research and Development Network Center, Khon Kaen University, Khon Kaen, Thailand, respectively. Initial body weight and agewere $613.3 \pm 12.5 \mathrm{~g}$ and 3 weeks in commercial broilers, and $601.2 \pm 15.8 \mathrm{~g}$ and 8 weeks in native chickens, respectively. Body weight was controlled to allow comparing the physiological responses of both groups. Birds were housed in individual cages in two separate rooms (thermoneutral and heat-stress rooms), fed twice daily with a conventional commercial broiler $\operatorname{diet}(20 \%$ CP; 3,250 kcal ME/kg), and given water ad libitum.

The heat stress conditions applied in the present study attempted to mimic the natural environment conditions of tropical regions, where temperatures increase with the intensity of daylight. Relative humidity was not artificially controlled. Heat stress was induced by increasing house temperature from $26{ }^{\circ} \mathrm{C}$ to $36^{\circ} \mathrm{C}$ for six hours daily (10 am to $4 \mathrm{pm}$ ), using thermostatcontrolled equipment with 20 light bulbs (200 watts). The other group was housed at room temperature, and the house temperature was set at $26^{\circ} \mathrm{C}$ from $10 \mathrm{am}$ to $4 \mathrm{pm}$, using an air conditioner.House temperature and relative humidity were recorded hourly using an automatic data logger. A 7-day adaptation period was applied before the collection of physiological data. Birds were closely monitored until the end of the experimental period of three weeks, when commercial broilers and native chickens were 7 and 10 weeks old, respectively.

\section{Data Collection}

The experiment was carried out for three weeks. Respiratory rate (RR; breaths/min), cloacal temperature $\left(\mathrm{CT} ;{ }^{\circ} \mathrm{C}\right)$, heterophil/lymphocyte ratio $(\mathrm{H} / \mathrm{L})$, and body weight (BW; g) were determined on days $1,7,14$, and 21.Physiological variables and blood samples were measured three hours after heat-stress induction. In addition, the body weight (BW), and feed intake (FI) were measured at $08.00 \mathrm{am}$. Average daily gain (ADG) and feed conversion ratio (FCR) were calculated considering the entire experimental period. Mortality rate was recorded during the experimental period.

In order to determine $\mathrm{H} / \mathrm{L}$ ratio, blood was individually collected from all experimental birds in Eppendorf tubes with EDTA on day 7, 14 and 21. Whole blood was smeared on a glass slide, and air dried for one minute. Each slide was fixed with absolute methyl alcohol, 
stained with Gimsa, heterophil and lymphocyte counts were performed under a microscope to calculate the $\mathrm{H} / \mathrm{L}$ ratio.

House temperature and humidity were hourly recorded by an automatic data logger. The temperaturehumidity index (THI) was calculated according to the formula $\mathrm{THI}=0.8 * T_{d b}+\mathrm{Rh} *\left(T_{d b}-14.4\right)+46.4$

where $T_{d b}$ is the temperature and $R h$ is the percentage of relative humidity (Hahn et al., 2009).

\section{HSP70 Genotyping}

Approximately $1 \mathrm{~mL}$ of blood was collected from the wing vein of each chicken, with $0.1 \mathrm{mLof} 0.5 \mathrm{M}$ EDTA added as an anticoagulant in the first experimental week. Genomic DNA was isolated using the guanidine method. Briefly, whole blood samples were washed twice with $0.9 \% \mathrm{NaCl}$ and centrifuged for five minutes at 2,500 rpm (Hermle Z323K rotor, Labnet International, Edison, NJ, USA). Thirty $\mu \mathrm{L}$ of blood cell pellets were transferred to a $1.5 \mathrm{~mL}$ tube, followed by the addition of $70 \mu \mathrm{L}$ of $20 \%$ SDS, $25 \mu \mathrm{L}$ of $1 \%$ proteinase $\mathrm{K}(1$ $\mathrm{mg} / \mathrm{mL}), 50 \mu \mathrm{L}$ of $7.5 \mathrm{~m}$ sodium acetate, and $740 \mu \mathrm{L}$ of cell lysis buffer ( $5 \mathrm{MGuHCl}, 20 \mathrm{mMTris}-\mathrm{HCl}$, and $0.5 \mathrm{M}$ EDTA). After vortexing, incubation at $60^{\circ} \mathrm{C}$ for 45-60 minutes, and centrifugation at 1,000 rpm for five minutes, the supernatant was transferred to a new microtube, to which absolute isopropanol was added. The DNA was precipitated at 14,000 rpm for 15 minutes. The supernatant was discarded, and the DNA pellet was washed 2-3 times with $75 \%$ ethanol. The DNA pellet was air-dried at room temperature and dissolved in a DNA hydration buffer. DNA quality and concentration were determined by UV spectroscopy (NanoVue, GE Healthcare, UK). The DNA was diluted to $50 \mathrm{mg} / \mu \mathrm{L}$ for use as a working solution and stored at $-20{ }^{\circ} \mathrm{C}$ before analyses.

The HSP70 gene was amplified by PCR, as explained in Mazzi et al. (2003). Primers HSP70-F (5'- AAC CGC ACC ACA CCC AGC TAT G - 3') and HSP70-R (5'- CTG GGA GTC GTT GAA GTA AGC G - 3') were used. The reaction was performed in a total volume of $20 \mu \mathrm{L}$ containing $100 \mathrm{mg}$ of genomic DNA ( $2 \mu \mathrm{L}$ of $50 \mathrm{mg} /$ $\mu \mathrm{L}$ genomic DNA), $0.5 \mathrm{M}$ of each primer $(2 \mu \mathrm{L}$ of $5 \mathrm{M}$ of each primer), $10 \mathrm{MdNTP}(2 \mu \mathrm{L}$ of $100 \mathrm{mMdNTP}), 5$ $\mathrm{M} \mathrm{MgCl}_{2}\left(2 \mu \mathrm{L}\right.$ of $\left.50 \mathrm{~m} \mathrm{MgCl}_{2}\right), 1 \times$ PCR buffer $(2 \mu \mathrm{L}$ of 10x PCR buffer), and 0.5 unit of Taq DNA polymerase (Promega, Madison, WI). Reactions were performed in a 96-well thermal cycler (GeneAmp ${ }^{\circledR}$ PCR System 9600, Perkin-Elmer/Applied Biosystems, Carlsbad, CA) according to the following cycling profile: initial denaturation at $94{ }^{\circ} \mathrm{C}$ for five minutes; 35 cycles at 94 ${ }^{\circ} \mathrm{C}$ for 30 seconds, $64{ }^{\circ} \mathrm{C}$ for 45 seconds, and $72{ }^{\circ} \mathrm{C}$ for 45 seconds; and a final extension at $72{ }^{\circ} \mathrm{C}$ for five minutes.

PCR products (360 bp) from individual chickens were genotyped for the loci $C$ and $M$ by digestion with Cfrl and Mmel (New England Biolabs, Ipswich, MA), respectively. The digestion reaction contained $4 \mu \mathrm{L}$ of PCR products, $2 \mu \mathrm{L} 10 \mathrm{x}$ buffer, and $5 \mathrm{U}$ enzymes, in a total volume of $20 \mu \mathrm{L}$ (incubated at $37^{\circ} \mathrm{C}$ overnight). DNA fragments were subjected to $2 \%$ agarose gel electrophoresis with $1 \mathrm{~m}$ TBE buffer ( $0.089 \mathrm{~m}$ Tris base, $0.089 \mathrm{~m}$ boric acid, and $0.002 \mathrm{~m}$ EDTA, pH 8.0). After electrophoresis at constant $100 \mathrm{~mA}$ and 100 Volt for 25 minutes, gels were stained with GelStar ${ }^{\circledR}$ (GelStar, Patchogue NY) for 10 minutes. DNA fragments were visualized by UV transillumination and photographed with a gel documentation system (Syngene, Cambridge, UK).

Genotype frequencies were determined separately for loci $C$ and $M$ according to the formula: $G_{i}=\sum n_{i} / N$ where $G_{i}$ is the $i$ genotype frequency, $n_{i}$ is the number of animals with genotype $i$, and $N$ is the total number of samples.

\section{Statistical Analysis}

A split-plot in time experimental design was applied. For the analysis of RR, CT, ADG, Fl, and FCR, the environmental temperature was set as the main plot, and chicken genetics was set as the subplot.Data were analysed according to the following model:

$$
y_{i j k l}=\mu+\rho_{i}+\alpha_{j}+\delta_{i j}+\beta_{k}+\alpha \tau_{j k}+\varepsilon_{i j k l}
$$

where $y_{i j k l}=$ observation, $\mu=$ overall mean, $\rho_{i}=$ effect of sex, $\alpha=$ effect of environmental temperature (thermoneutral or heat stress), $\delta_{\mathrm{ij}}=$ main plot error, $\beta_{k}=$ effect of genetics (commercial broilers or native chickens), $\alpha \tau_{\mathrm{jk}}=$ effect of the environmental temperature $\times$ genetic interaction, and $\varepsilon_{\mathrm{ijk} \mid}=$ subplot error. Means were compared by Duncan's new multiple range test. For the analysis of the $\mathrm{H} / \mathrm{L}$ ratio, the subplot measures repeated on days 1, 7, 14, and 21 were included.

\section{Experiment II: Effect of the HSP70 genotype on the heat tolerance of native chickens}

The objective of experiment II was to study the effect of the HSP70 genotype on the heat tolerance in native chickens. Based on the results of experiment I, allele C1 may be a putative allele for heat stress tolerance. However, the HSP70 genotypes found in the samples were not equally distributed, and no C1C1 was detected in this experiment. Therefore, 
Duangjinda M, Tunim S, Duangdaen C, Boonkum W
Hsp70 Genotypes and Heat Tolerance of Commercial and Native Chickens Reared in Hot and Humid Conditions the three genotypes $(\mathrm{C} 1 \mathrm{C} 1, \mathrm{C} 1 \mathrm{C} 2$, and $\mathrm{C} 2 \mathrm{C} 2)$ were simultaneously evaluated. In Experiment II, native chicken mating was designed to obtain these three genotypes in the offspring. The three genotypes $(C 1 C 1, C 1 C 2$, and $C 2 C 2)$ were produced by mating $\mathrm{C} 1 \mathrm{C}_{1} \times \mathrm{C} 1 \mathrm{C} 1, \mathrm{C} 1 \mathrm{C} 1 \times \mathrm{C} 2 \mathrm{C} 2$, and $\mathrm{C} 2 \mathrm{C} 2 \times \mathrm{C} 2 \mathrm{C} 2$ parents (30 sires and 150 dams per mating group). In order prevent confusion with locus $\mathrm{M}$, parents with the $\mathrm{M} 1 \mathrm{M} 1$ and $\mathrm{M} 1 \mathrm{M} 2$ genotypes were discarded from the study, as $<5 \%$ of both genotypes were found in native chickens. Therefore, only M2M2 parents were used in Experiment II.

All chickens were reared according to identical management procedures and fed the same feed. The experiment was conducted from August to December, 2010, on the experimental farm of Khon Kaen University, Khon Kaen, Thailand. DNA isolation and genotyping were conducted in the Laboratory of Animal Biotechnology, Department of Animal Science, Khon Kaen University.

\section{Management and Induction of Heat Stress}

Before the beginning of the experiment, all birds were reared in an environmentally-controlled house. Birds were submitted to heat stress four weeks before market age. Because Thai indigenous chickens typically achieve market weight at 14-16 weeks of age, 10-wkold chickens were used in this experiment. Birds of the genotypes C1C1 $(n=38), C 1 C 2(n=38)$, and C2C2 ( $=28$ ) were randomly divided in two groups with equal numbers of males and females and submitted to heat stress or not. Each group was randomly assigned into separate closed compartments ( $3.5 \times 8 \mathrm{~m}$ each) in the same room equipped with ventilation. Chickens were kept in individual cages in each compartment and received feed twice daily and water ad libitum. Birds were submitted to a 7-day adaptation period before the treatments were applied. The temperature heat-stress room was increased to $36{ }^{\circ} \mathrm{C}$ for six hours daily (10 am to $4 \mathrm{pm}$ ) using thermostat-controlled equipment with 9 bulbs (250 watts). In the thermoneutral room, temperature was set at $26{ }^{\circ} \mathrm{C}$ and maintained air conditioner equipment. Birds were closely monitored during until the end of the 3-week experimental period. House temperature and relative humidity were recorded hourly using an automatic data logger.

\section{Data Collection and HSP70 Genotyping}

Respiratory rate (RR; breaths/min), cloacal temperature $\left(\mathrm{CT} ;{ }^{\circ} \mathrm{C}\right)$, packed cell volume $(\mathrm{PCV} ; \%)$, and heterophil/lymphocyte ratio $(\mathrm{H} / \mathrm{L})$ were determined weekly three hours after heat-stress induction for four weeks. Body weight (BW; g) was measured at 08.00 am on the following day, and was used to calculate average daily gain (ADG; $g / d$ ). Thereafter, these parameters were collected weekly from 10 to 14 weeks of age.

For PCV measurement, a hematocrit capillary was used to collect blood from the wing vein of individual birds, followed by centrifugation at $12,000 \mathrm{rpm}$ for five minutes. The PCV was calculated as volume of red blood cells relative to whole blood volume, using the hematocrit scale, and expressed as percentage. The H/L ratios were determined as described in Experiment $\mathrm{I}$.

The HSP70 genotypes in the offspring were examined using primers, as described in Experiment I. PCR products were digested with C frl (New England Biolabs, Ipswich, MA, USA) to confirm the mating genotypes. The digestive reaction is detailed in the previous experiment.

\section{Statistical Analysis}

A split-plot in time experimental design was applied. The HSP70 genotype was set as the main plot, and time (weeks) was set as the subplot. Physiological data were analysed separately for both thermoneutral and heat stress conditions, using the following model:

$$
y_{i j k l m}=\mu+\beta_{i}+\rho_{j}+\alpha_{k}+\delta_{k l}+\tau_{m}+\alpha \tau_{k m}+\varepsilon_{i j k l m}
$$

Where $\mathrm{y}_{\mathrm{ijk} \mathrm{k}}=$ observation, $\mu=$ overall mean, $\beta_{\mathrm{i}}=$ effect of sex, $\rho_{\mathrm{j}}=$ effect of hatch number, $\alpha_{\mathrm{k}}=$ effect of HSP70 genotype (C1C1/M2M2, C1C2/M2M2, and C2C2/M2M2), $\tau_{m}=$ effect of time, $\alpha \tau_{\mathrm{km}}=$ main plot error, $\varepsilon_{\mathrm{ijklm}}=$ effect of genotype $\times$ time interaction, and $\varepsilon_{i \mathrm{ijkm}}=$ subplot error. Means were compared by Duncan's new multiple range test. Trends of the physiological and daily gain responses during the experimental period were analyzed by orthogonal polynomials.

\section{RESULTS AND DISCUSSION}

\section{Experiment I: Effects of Heat Stress on Commercial broilers and Thai Native Chickens}

Daytime THI values observed during the three weeks of the experiment are shown in Figure 1. There was a clear difference in $\mathrm{THI}$ patterns between the control and heat stress environments, and the maximum $\mathrm{THI}$ difference (approximately 10 degrees of $\mathrm{THI}$ ) was recorded between 12:00 to 14:00 hours.

\section{Effects of Heat Stress on Growth Performance and Mortality}

The results clearly show the growth performance differences between of two genetic strains reared 

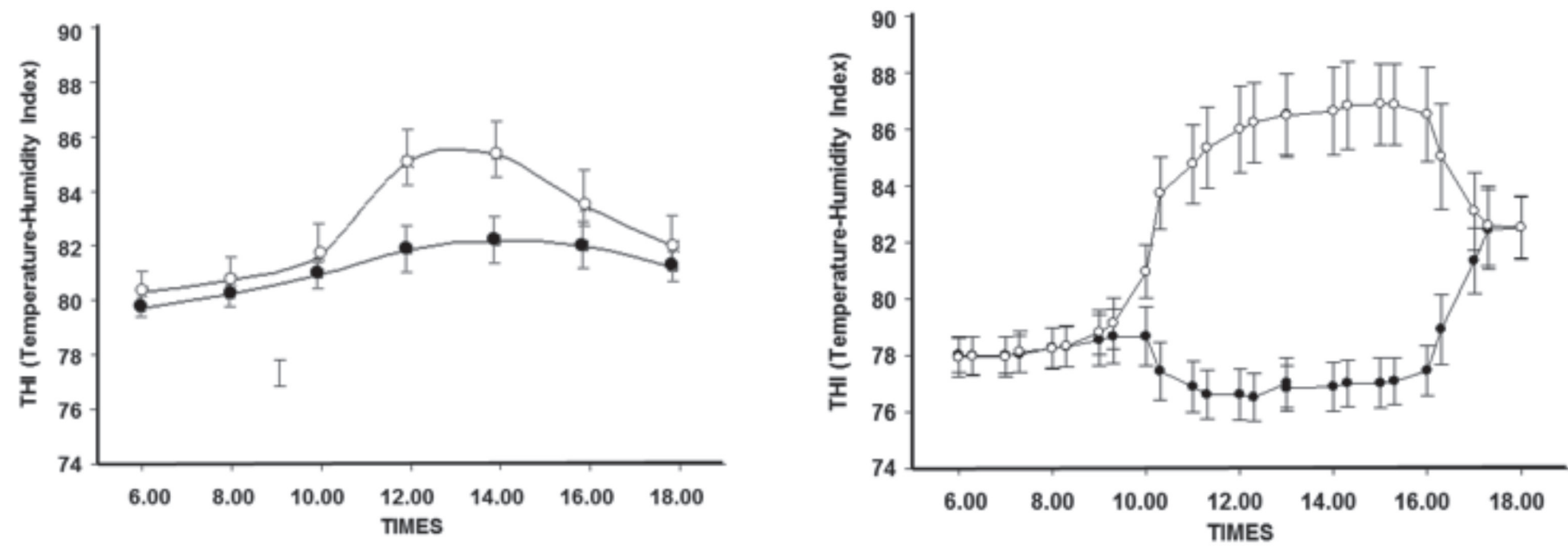

Figure 1 -Temperature-humidity index from 6 a.m. to 6 p.m. in the heat-stress environment at $36 \pm 2^{\circ} \mathrm{C}(\mathbf{O})$, and thermoneutral environment $26 \pm 2{ }^{\circ} \mathrm{C}(\bullet)$ recorded in Experiments I (a) and II (b).

under different temperatures (Table 1). The average daily gain (ADG) and feed intake ( $\mathrm{Fl}$ ) of commercial broilers were significantly $(p<0.05)$ reduced under heat stress conditions. On the other hand, the ADG of native chickens was not affected by heat stress, indicating the heat tolerance of this native breed. No feed conversion ratio (FCR) differences were detected ( $p>0.05$ ) between treatments within the same genetics. However, genetic $x$ environmental interactions (GxE) were observed. The rate of ADG reduction in commercial broilers (20.4\%) was twice as high as in native chickens $(9.6 \%)$ when temperature was increased from $26( \pm 2){ }^{\circ} \mathrm{C}$ to $36( \pm 2)$ ${ }^{\circ} \mathrm{C}$. In contrast, the rate of $\mathrm{Fl}$ reduction in commercial broilers $(7.9 \%)$ was nearly twice as low as in native chickens $(14.0 \%)$. Due to their lower tolerance to heat, the mortality rate of commercial broilers (46.0\%) was extremely high, whereas it was only $2 \%$ in native chickens (2\%). Reduced feed intake and growth performance due to heat stress has been documented in several reports (Mehta \& Singari, 1999; Yuming et al., 1999; Altan et al., 2000; Oliveira et al., 2000;
Temim et al., 2000; Deeb \& Cahaner, 2001; Xin et al., 2002).

\section{Effects of heat stress on physiological responses}

Under thermoneutral environments, body temperature of chickens should range between 41 $42{ }^{\circ} \mathrm{C}$ (Donkoh, 1989; Reddy, 2000). When submitted to high environmental temperatures $\left(36^{\circ} \mathrm{C}\right)$, broiler body temperature increases, resulting in panting and high water consumption (Pathom, 1997; Cooper \& Washburn, 1998; Zhou et al., 1999; Puvadolpirod \& Thaxton, 2000). Therefore, body temperature is an indicator of heat stress tolerance. In the present study, the cloacal temperature of commercial broilers was higher $(p<0.05)$ than that of native chickens, in both under thermoneutral and heat stress conditions. Increased cloacal temperatures in birds of both evaluated genotypes were observed from days 1 to 21 of the experiment in the heat-stress environment. Panting is the main route for heat dissipation in chickens, according to Aengwanich (2007), who also reported higher heat tolerance in Thai native chickens

Table 1 - Effect of heat stress on the respiratory rate, cloacal temperature, average daily gain, feed intake, feed conversion ratio and mortality of commercial broilers and Thai native chickens maintained at thermoneutral $\left(26 \pm 2{ }^{\circ} \mathrm{C}\right)$ or heat stress $\left(38 \pm 2^{\circ} \mathrm{C}\right)$ temperatures.

\begin{tabular}{|c|c|c|c|c|c|}
\hline & \multicolumn{2}{|c|}{ Commercial Broilers } & \multicolumn{2}{|c|}{ Thai Native chicken } & \multirow{2}{*}{ SEM } \\
\hline & $26 \pm 2^{\circ} \mathrm{C}$ & $38 \pm 2^{\circ} \mathrm{C}$ & $26 \pm 2^{\circ} \mathrm{C}$ & $38 \pm 2^{\circ} \mathrm{C}$ & \\
\hline Respiratory rate, RR (breaths/min) & $39.18^{b}$ & $162.57^{c}$ & $33.26^{a}$ & $158.87^{c}$ & 1.54 \\
\hline Cloacal temperature, $\mathrm{CT}\left({ }^{\circ} \mathrm{C}\right)$ & $41.58^{b}$ & $43.14^{d}$ & $41.42^{a}$ & $42.24^{c}$ & 0.04 \\
\hline Average daily gain, ADG (g/d) & $42.26^{\mathrm{a}}$ & $33.63^{b}$ & $17.47^{c}$ & $15.78^{c}$ & 1.70 \\
\hline Feed intake, Fl (g/d) & $87.31^{a}$ & $80.33^{b}$ & $72.21^{c}$ & $62.09^{d}$ & 2.12 \\
\hline Feed conversion ratio, FCR & $2.08^{a}$ & $2.39^{a}$ & $4.13^{b}$ & $4.09^{b}$ & 0.23 \\
\hline Mortality (\%) & 0.00 & 46.00 & 0.00 & 2.00 & - \\
\hline
\end{tabular}

a,b Means with different superscripts indicate significant differences between genetic strains $(p<0.05)$. 
Duangjinda M, Tunim S, Duangdaen C, Boonkum W

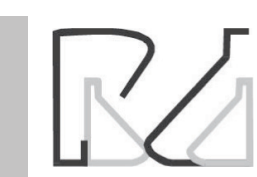

Hsp70 Genotypes and Heat Tolerance of Commercial and Native Chickens Reared in Hot and Humid Conditions

than in commercial broiler strains when reared in hot temperatures $\left(38 \pm 1^{\circ} \mathrm{C}\right)$.

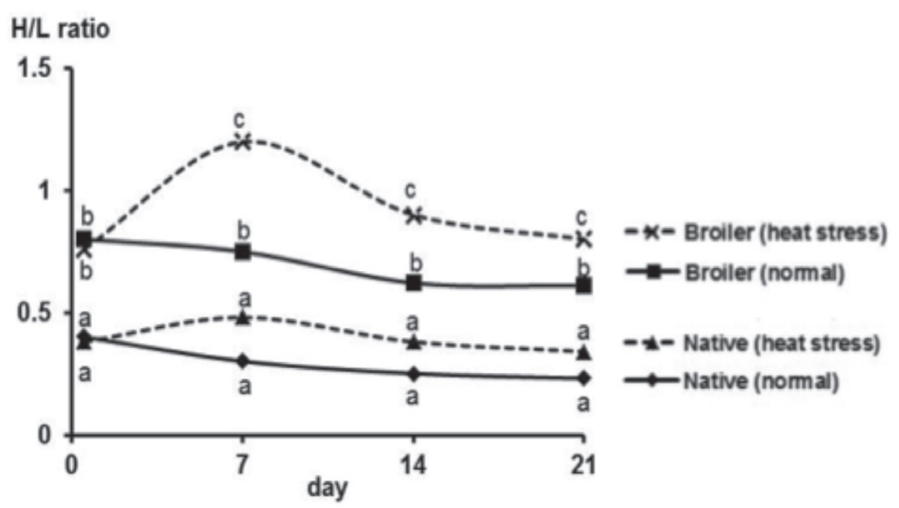

Figure 2 - Heterophil:lymphocyte (H/L) ratio measured on days 0, 7, 14 and 21 of the experiment of commercial broilers and Thai native chickens maintained at thermoneutral $(26 \pm 2 \mathrm{oC})$ or heat stress ( $38 \pm 2 \mathrm{oC})$ temperatures. Different letters within the same day indicate significant differences among groups $(p<0.05)$.

\section{Experiment II: Effect of the HSP70 genotype on the heat tolerance of native chickens}

\section{HSP70 Genotypes}

The polymerase chain reaction with the given primer gave a PCR product size of $360 \mathrm{bp}$. The genotype at locus C was defined after cutting with Crfl; a fragment size of $229 \mathrm{bp}$ was indicated for the $\mathrm{C} 1$ allele, and of $240 \mathrm{bp}$ for the C2 allele. The genotype at locus M was defined after cutting with Mmel; a fragment size of $229 \mathrm{bp}$ was indicated for the M1 allele, and of $360 \mathrm{bp}$ (non-cutting) for the $\mathrm{M} 2$ allele. The expected $\mathrm{C} 1 \mathrm{C} 1$, $\mathrm{C} 2 \mathrm{C} 2$, and $\mathrm{C} 1 \mathrm{C} 2$ genotypes from $\mathrm{C} 1 \mathrm{C} 1 \times \mathrm{C} 1 \mathrm{C} 1$, $\mathrm{C} 2 \mathrm{C} 2 \times \mathrm{C} 2 \mathrm{C} 2$, and $\mathrm{C} 1 \mathrm{C} 1 \times \mathrm{C} 2 \mathrm{C} 2$ parents, respectively,

\section{(a) Cfr $I$}

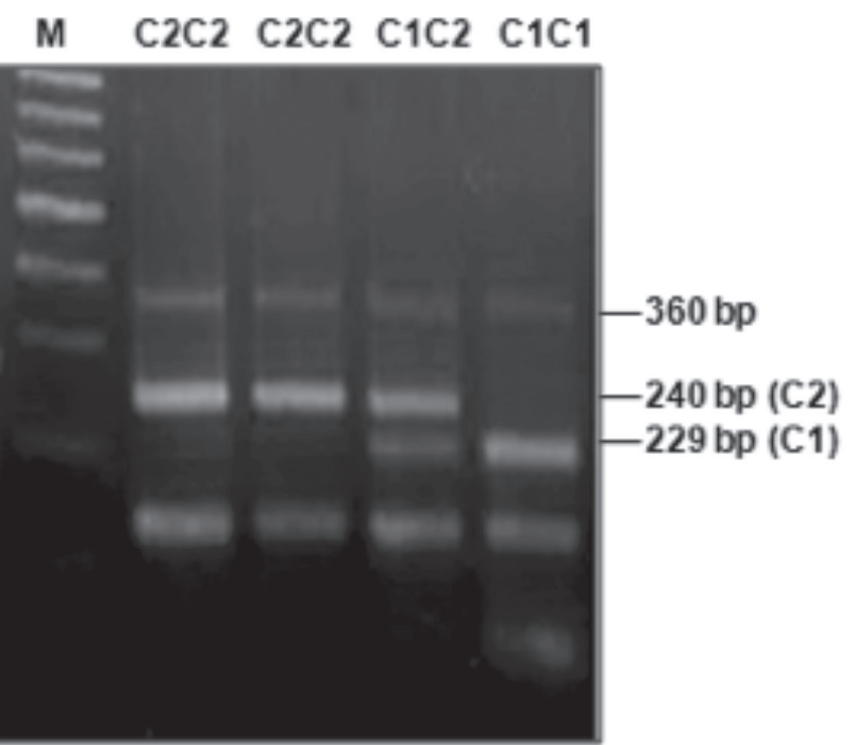

were confirmed by PCR-RFLP. All chickens were also confirmed for the M2M2 genotype. A total of 102 chicken genotypes at locus $C$ and locus $M$ were also confirmed. The fragments from gel electrophoresis indicating genotypes $\mathrm{C} 1 \mathrm{C} 1, \mathrm{C} 1 \mathrm{C} 2$, and $\mathrm{C} 2 \mathrm{C2}$ are shown in Figure 3.

\section{Effect of HSP70 genotypes on physiological responses}

The effects of genotypes on the physiological responses, as measured by respiratory rate (RR) and cloacal temperature (CT) under both control and heat-stress conditions, are shown in Table 2.The RR of native chickens submitted to heat stress was significantly higher than that of the controls. No $R R$ and $C T$ differences ( $p>0.05$ ) among genotypes were detected in none of the experimental weeks. The considerable RR increase in chickens under heat stress was in agreement with several previous reports (Abu-Dieyeh, 2006; Aengwanich \& Suttajit, 2010). Body heat dissipation increased with increasing RR, but $C T$ remained unchanged. The absence of effects of genotypes on RR and CT is in agreement with Duangduen (2007) and Puvadolpirod \& Thaxton (2000). The evaluated parameters were different between environments. Under heat stress, during the three-week period, RR and CT presented cubic $(p<0.01)$ and tentatively quadratic $(p<0.10)$ polynomial responses, respectively (Figure 4 ). The rate of $R R$ increase was high during the first week after exposure to heat, and then gradually slowed until the third

\section{(b) $\mathrm{MmeI}$}

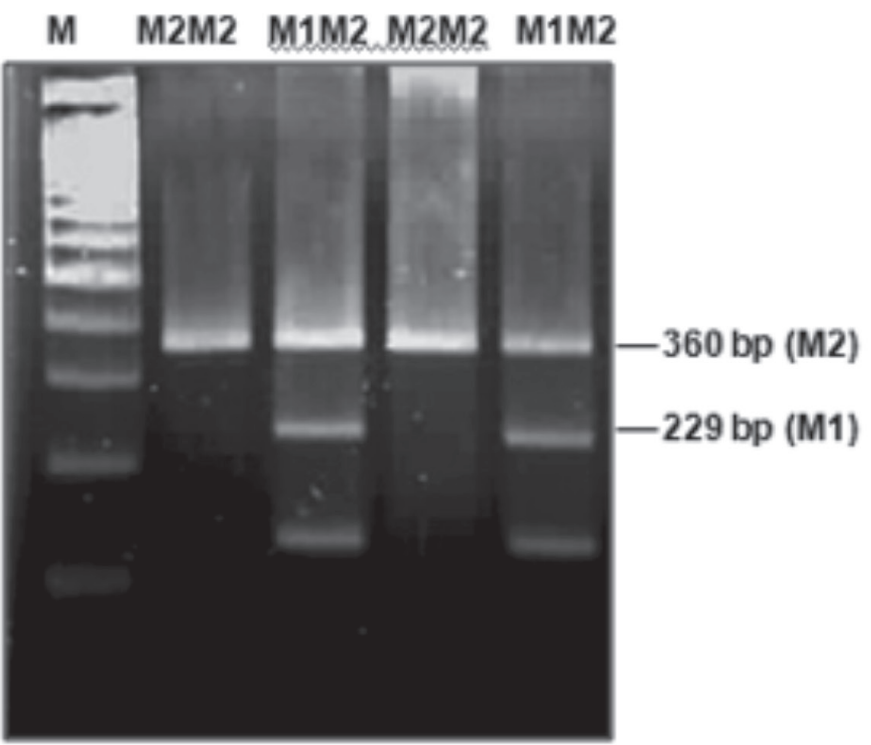

Figure 3 - DNA bands from PCR and polymorphism of HSP70 by PCR-RFLP, showing PCR product size of 360 bp. Genotype at locus C: fragment size of 229 bp for the C1 allele and of $240 \mathrm{bp}$ for the C2 allele. Genotype at locus M: fragment size of $229 \mathrm{bp}$ for the M1 allele and of $360 \mathrm{bp}$ for the M2 allele. 
Duangjinda M, Tunim S, Duangdaen C, Boonkum W

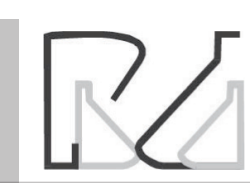

week. This pattern indicates that the birds acclimated to the hot temperature (Moberg \& Menh, 2000). CT peaked in the second week and then remained stable. In the heat-stressed chickens, RR was more than four times higher than that of chickens maintained in the thermoneutral environment.

Table 2 - Genotypic frequency distribution for the loci $C$ and $\mathrm{M}$ in commercial broilers and Thai native chickens.

\begin{tabular}{lccccccc}
\hline & \multicolumn{3}{c}{ Locus $~$} & & \multicolumn{3}{c}{ Locus M } \\
\cline { 2 - 4 } \cline { 7 - 8 } & C1C1 & C1C2 & C2C2 & & M1M1 & M1M2 & M2M2 \\
\hline $\begin{array}{l}\text { Commercial } \\
\text { broilers }\end{array}$ & - & 0.08 & 0.92 & & - & 0.15 & 0.85 \\
Native chicken & 0.18 & 0.54 & 0.28 & & - & 0.07 & 0.93 \\
\hline
\end{tabular}
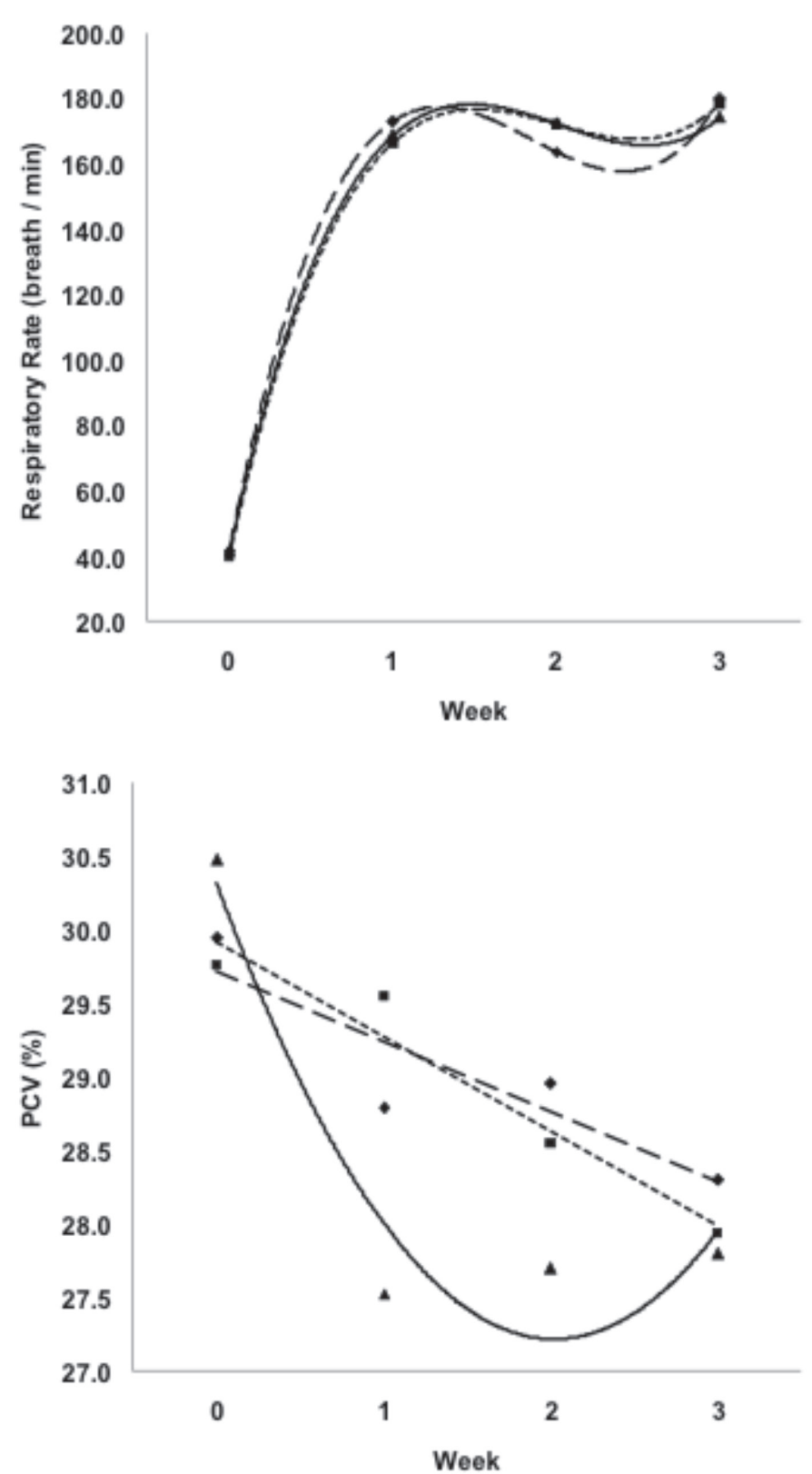

Hsp70 Genotypes and Heat Tolerance of Commercial and Native Chickens Reared in Hot and Humid Conditions

\section{Effect of HSP70 Genotypes on Hematological Response}

The effects of genotypes on hematological response, as measured by packed cell volume (PCV) and heterophil/lymphocyte ratio $(\mathrm{H} / \mathrm{L})$ under thermoneutral and heat stress conditions are shown in Table 3. Under heat stress, PCV presented different patterns among genotypes. The PCV of Thai native chickens is typically 28-37\% (Simaraks et al., 2004). In this study, the PCV of control chickens was ranged between 29.79 and $30.48 \%$. Under heat stress conditions, PCV linearly $(p<0.01)$ decreased in $\mathrm{C} 1 \mathrm{C} 1$ and $\mathrm{C} 1 \mathrm{C} 2$ genotypes, whereas $C 2 C 2$ presented a quadratic $(p<0.01)$
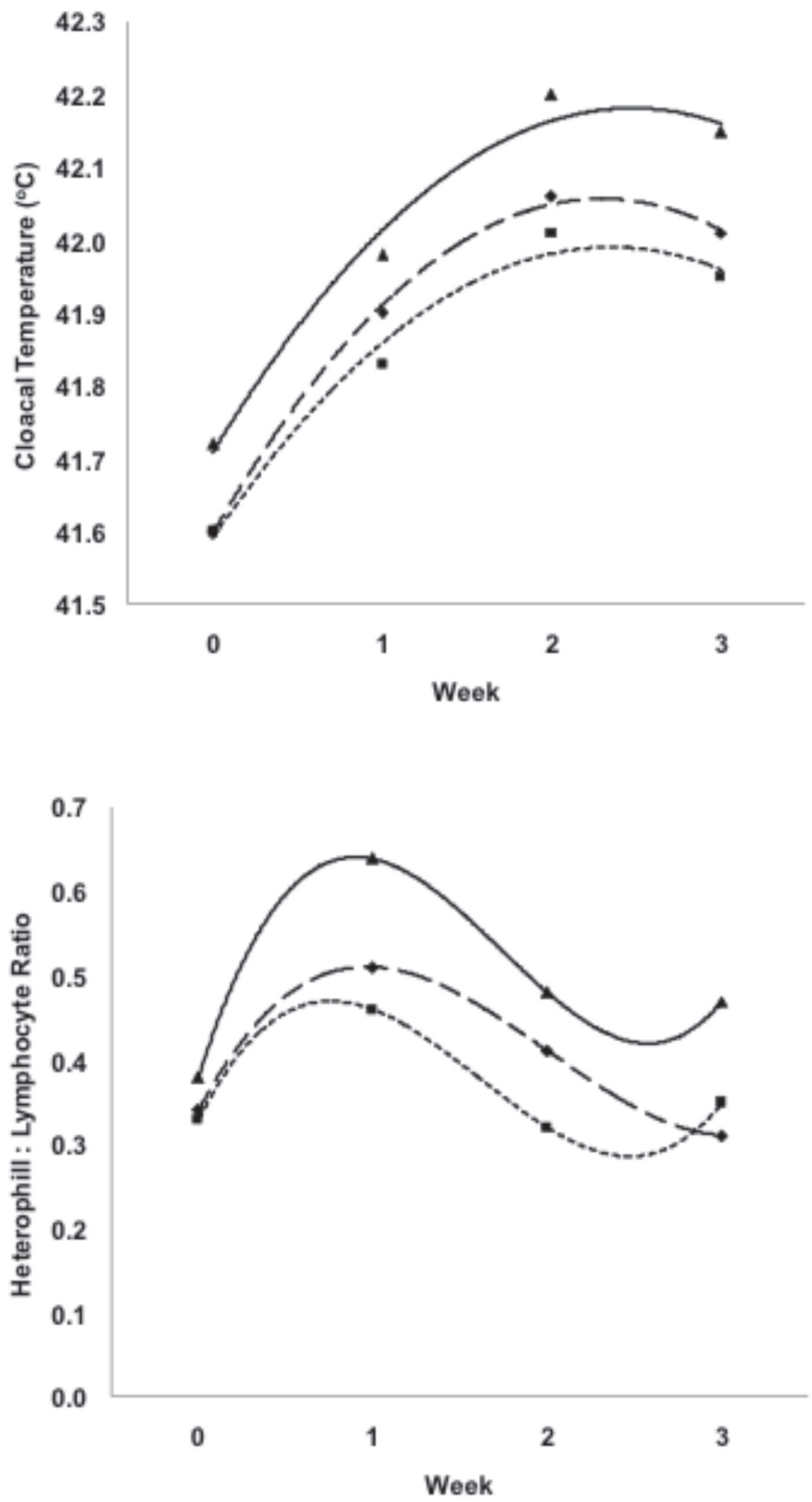

Figure 4 - Responses and trends of: a) respiratory rate, b) cloacal temperature, c) packed cell volume, and d) heterophil/lymphocyte ratio before heat stress (week 0) and during heat

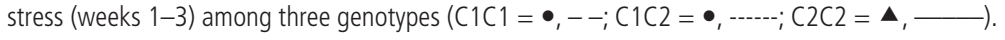




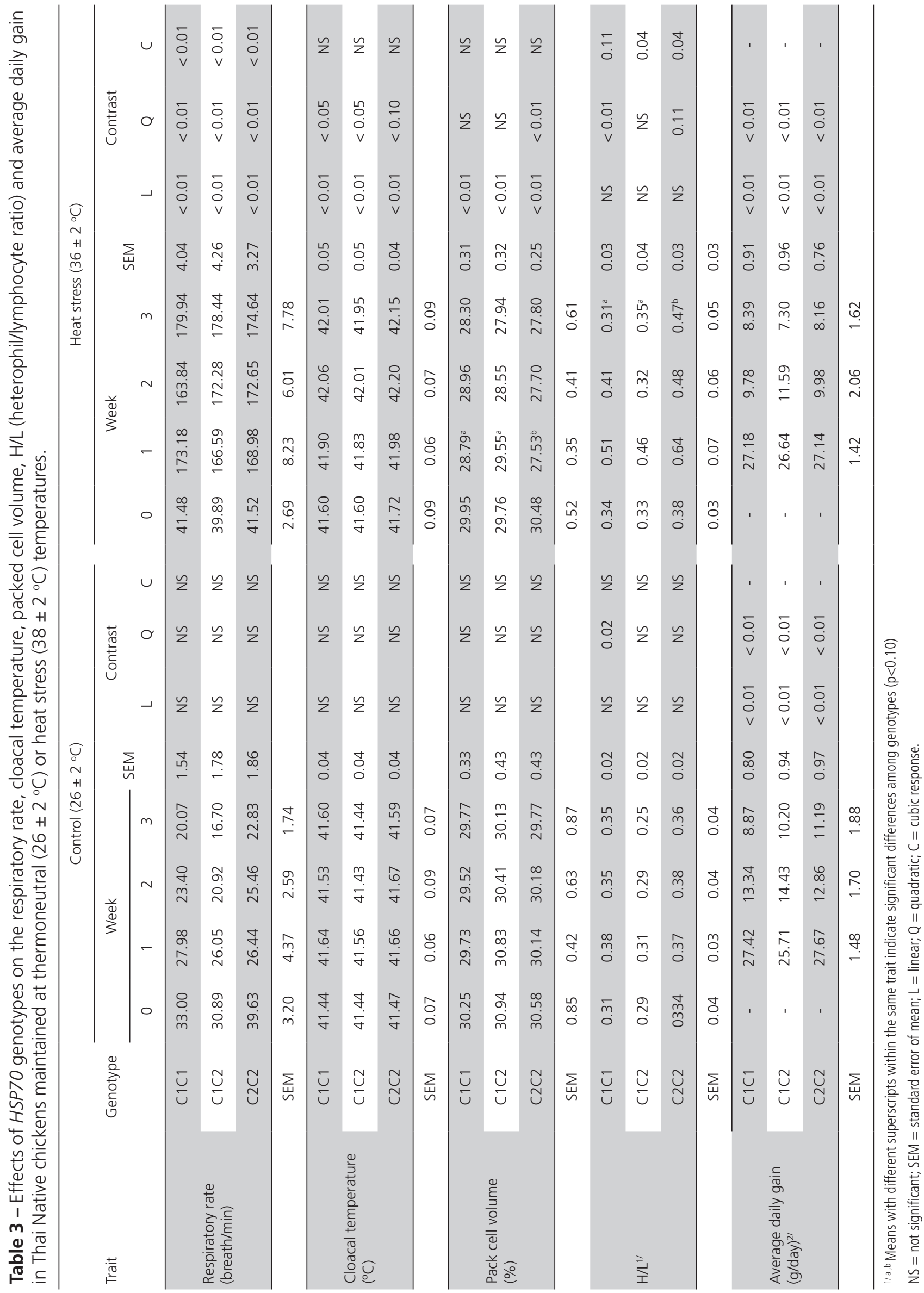


decreasing response. The decrease of PCV in chickens under heat stress was in agreement with the report by Altan et al. (2003). PCV decreases because heat is released from the cells by losing water to the interstitial fluid and blood circulation. The increase of water in the plasma, therefore, reduces the PCV (Abdel-Azeemet et al., 2007). Hemodilution is an important mechanism related to evaporative heat loss (El-Nouty et al., 1990) in Thai indigenous chickens. Figure 4c shows that the PCV of C2C2 chickens under heat stress decreased quadratically ( $p<0.01)$, while C1C1 and C1C2 chickens presented a linear $(p<0.01)$ reduction. The PCV difference between the C2C2 (27.53\%) and the C1C1 (28.79\%) and C1C2 (29.55\%) genotypes tended to be different $(p<0.10)$. The rapid PCV decrease observed in the first week of heat stress shows that the C2C2 chickens were more sensitive to heat stress. However, all genotypes presented similar PCV values by the third week. This indicates that the PCV recovery time from heat stress effect is of at least two weeks.

The $H / L$ ratio is an acceptable indicator of heat stress (Gross \& Siegel, 1983). It has also been found to be related to blood glucocorticoids levels (Davis et al., 2008). Therefore, $H / L$ has been used to evaluate the welfare of chickens in stressful environments (Altan et al., 2000). In the present study, the $\mathrm{H} / \mathrm{L}$ of $\mathrm{C} 1 \mathrm{C} 1$ chickens presented a quadratic response $(p<0.05)$ and $C 1 C 2$ and $C 2 C 2$ a cubic response $(p<0.05)$ under heat stress (Figure $4 d$ ). The $H / L$ sharply increased after the first week of heat exposure, but tended to return to normal level by the third week due to homeostasis. This increase of $\mathrm{H} / \mathrm{L}$ in response to heat stress response is consistent with Zulkifli et al. (2000a), who observed a significant $\mathrm{H} / \mathrm{L}$ increase in broilers around 4-7 days after exposure to heat stress. Similar findings were reported by Aengwanich (2007) and Duangduen et al. (2007). The increase of $\mathrm{H} / \mathrm{L}$ under chronic heat stress is explained by the simultaneous increase in heterophils and decrease in lymphocytes in response to glucocorticoid hormones (stress hormones), which promote the release of heterophils from the bone marrow into the circulation (Bishop et al., 1968). This may further cause an increase in the attachment of lymphocytes to the vascular epithelial lining (Fauci, 1975; Dhabhar, 2002). $\mathrm{H} / \mathrm{L}$ ratios of $0.2,0.5$, and 0.8 have been suggested as indicators of no stress, moderate, and severe stress in chickens, respectively (Gross \& Siegel, 1983). According to this criterion, Thai native chickens in our study were not stressed under thermoneutral conditions and were moderately stressed under heat stress. Previous reports (Aengwanich, 2007; Duangduen et al., 2007) showed that broilers may present moderate stress $(\mathrm{H} / \mathrm{L}$ in a range of 0.4-0.5) even under thermoneutral conditions, and severe stress when submitted to heat stress $(H / L$ in a range of 0.6-0.9). Our results show that $C 2 C 2$ chickens presented a wide oscillation of $\mathrm{H} / \mathrm{L}$ ratio, especially in the first week, indicating that this genotype was sensitive to heat stress. The significantly higher $(p<0.01) \mathrm{H} / \mathrm{L}$ ratios of C2C2 compared with other genotypes in the third week indicates the unsuccessful recovery of $\mathrm{H} / \mathrm{L}$ in C2C2 chickens.

\section{Effect of HSP70 Genotypes on Average Daily Gain}

The effects of genotype on average daily gain (ADG) under control or heat stress conditions are shown in Table 3. Chickens in the heat stressed group presented slightly lower ADG than the control group. However, no significant differences in ADG among genotypes ( $p>0.05)$ maintained under either condition were detected. The quadratic reduction $(p<0.01)$ of ADG over the three-week period can be attributed to the increasing age of the chickens. The lack of ADG differences between heat-stressed and control chickens is also in agreement with the findings of Aengwanich (2007) and Duangduen (2007). On the other hand, ADG reduction due to heat stress is commonly observed in commercial broiler chickens (Cooper \& Washburn, 1998; Altan et al., 2000).

The results of this study indicate that RR, PCV and $\mathrm{H} / \mathrm{L}$ are effective indicators for heat stress in chickens. Significant responses to heat stress - increasing RR to remove heat from the body, increasing hemodilution (decreasing PCV) to remove heat from the cells, and increasing $\mathrm{H} / \mathrm{L}$ ratios in response to glucocorticoid hormones - were demonstrated in our study. The HSP70 genotypes presented different tolerances to heat stress. The C2C2 genotype presented the highest susceptibility to heat stress. Therefore, the selection of C 1C 1 or C1C2 genotypes may be applied in commercial poultry breeding programs to enhance heat tolerance.

\section{ACKNOWLEDGMENTS}

The authors thank the Research and Development Network Center for Animal Breeding (native chickens), and KKU-TRF for supplying blood samples and data. This study was also supported by the Higher Education Research Promotion and National Research University Project of Thailand, the Office of the Higher Education Commission, and the Food and Functional Food Research Cluster at Khon Kaen University. Acknowledgement is extended to Khon Kaen University's Faculty of Agriculture for providing financial support for manuscript preparation. 


\section{REFERENCES}

Abdel-Azeem AS, Abdel-Azim AM, Darwish, AA, Omar EM. Hematology and biochemistry of pure and crossed rabbits. Proceedings of the 5th International Confernece on Rabbit Production in Hot Climates; 2007; Hurghada. Egypt. p. 391-401.

Abu-Dieyeh ZHM. Effect of high temperature per se on growth performance of broilers. International Journal of Poultry Science 2006;5:19-21.

Aengwanich W. Comparative ability to tolerate heat between Thai indigenous chickens, Thai indigenous chickens crossbred and broilers by using heterophil/lymphocyte ratio.Pakistan Journal of Biological Sciences 2007;10(11):1840-1844.

Aengwanich W. Effects of high environmental temperature on the productive performance of Thai indigenous, Thai indigenous crossbred, and broiler chickens. International Journal of Poultry Science 2007b;6:349-353.

Aengwanich W, Suttajit M. Effect of polyphenols extracted from tamarind (Tamarindusindica L.) seed coat on physiological changes, heterophil/ lymphocyte ratio, oxidative stress and body weight of broilers (Gallus domesticus) under chronic heat stress. Animal Science Journal 2010;81:264-270.

Al-Fataftah AA, Abu-Dieyeh ZHM. Effect of chronic heat stress on broiler performance in Jordan. International Journal of Poultry Science 2007;6:64-70.

AltanO, Pabuçcuoğlu A, Altan A, Konyalioğlu S, Bayraktar H. Effect of heat stress on oxidative stress, lipid peroxidation and some stress parameters in broilers. British Poultry Science 2003;44:545-550.

Altan O, Altan A, Oğuz I, Pabuçcuoğlu A,Konyalioğlu S. Effects of heat stress on growth, some blood variables and lipid oxidation in broilers exposed to high temperature at an early age. British Poultry Science 2000;41:489-493.

Bishop CR, Athens JW, Boggs DR, Warner HR, Cartwright GE, Wintrobe MM. Leukokinetic studies 13. A non-steady-state kinetic evaluation of the mechanism of cortisone-induced granulocytosis.Journal of Clinical Investigation 1968;47:249-260.

Bekele F, Ådnøy T, Gjøen HM, Kathle J, Abebe G. Production Performance of Dual Purpose Crosses of Two Indigenous with Two Exotic Chicken Breeds in Sub-tropical Environment.International Journal of Poultry Science 2010;9:702-710.

Borges SA, Fischer da Silva AV, Majorka A, Hooge DM, Cummings KR. Physiological responses of broiler chickens to heat stress and dietary electrolyte balance (sodium plus potassium minus chloride, milliequivalents per kilogram). Poultry Science 2004;83:1551-1558.

Bruno LDG, Maiorka A, Macari M, Furlan RL, Givisiez PEN. Water intake behavior of broiler chickens exposed to heat stress and drinking from bell or and nipple drinkers. Revista Brasileira de Ciência Avícola 2011;13:147-152.

Cooper MA, Washburn KW. The relationships of body temperature to weight gain, feed consumption, and feed utilization in broilers under heat stress. Poultry Science 1998;77:237-242.

Dhabhar FS. A hassle a day may keep the doctor away: stress and the augmentation of immune function. Integrative and Comparative Biology 2002;42:556-564.

Daghir NJ. Poultry production in hot climates. Wallingford: CABI Publishing; 1995.

Davis AK, Maney DL, Maerz JC. The use of leukocyte profiles to measure stress in vertebrates: a review for ecologists. Functional Ecology 2008;22:760-772.
Duangduen C, Duangjinda M, Katawatin S, Aengwanich W. Effects of heat stress on growth performance and physiological response in Thai indigenous chickens (Chee) and broilers. Kasetsart Veterinarians 2007;17:122-133.

El-Gendy E, Washburn KW. Genetic variation in body temperature and its response to short-term acute heat stress in broilers. Poultry Science 1995;74:225-230.

El-Nouty FD, Hassan GA, Taher TH, Samak MA, Abo-Elezz Z, SalemH Water requirements and metabolism in Egyptian Barki and Rahmani sheep and Baladi goats during spring, summer and winter seasons. The Journal of Agricultural Science 1988;111(1):27-34.

Ewing SA, Jr Lay DC, von Borell E. Farm animal well-being: stress physiology, animal behavior and environmental design. New Jersey: Prentice-HalL; 1999.

Fauci AS. Mechanisms of corticosteroid action on lymphocyte subpopulations. 1. Redistribution of circulating $T$ and $B$ lymphocytes to the bone marrow. Immunology 1975;28:669-680.

Fotsa J, Mérat $P$, Bordas $A$. Effect of the slow $(K)$ or rapid $(k+)$ feathering gene on body and feather growth and fatness according to ambient temperature in a Leghorn x brown egg type cross. Genetics Selection Evolution 2001;33:659-670.

Gross WB, Siegel HS. Evaluation of the heterophil/lymphocyte ratio as a measure of stress in chickens. Avian Disease 1983:27:972-979.

Guerreiro EN, Giachetto PF, Givisiez PEN, Ferro JA, Ferro MIT, Gabriel $\mathrm{JE}$, et al. Brain and hepatic Hsp70 protein levels in heat-acclimated broiler chickens during heat stress. RevistaBrasileira de Ciência Avícola 2004;6:201-206.

Hahn GL, Gaughan JB, Mader TL, Eigenberg RA.T hermal indices and their applications for livestock environments. In: De Shazer JA, editor. Livestock energetics and thermal environment management. St Joseph: American Society of Agricultural and Biological Engineers; 2009. p. 113-130.

Kiang JG, Tsokos GC. Heat shock protein 70 kDa: molecular biology, biochemistry, and physiology. Pharmacology and Therapeutics 1998;80:183-201.

Kingori AM, Wachira AM, Tuitoek JK. Indigenous chicken production in kenya: a review. International Journal of Poultry Science 2010;9:309316 .

Mashaly MM, Hendricks GL, Kalama MA, Gehad AE, Abbas AO, Patterson $\mathrm{PH}$. Effect of heat stress on production parameters and immune responses of commercial laying hens. Poultry Science 2004;83:889894.

Mazzi CM, Ferro JA, Ferro MIT, Savino VJM, Coelho AAD, Macari M. Polymorphism analysis of the HSP70 stress gene in Broiler chickens (Gallus gallus) of different breeds. Genetics and Molecular Biology 2003;26:275-281.

Mekki DM, Yousif IA, Rahman MKA, Wang J, Musa HH. Growth performanceof indigenous $X$ exotic crosses of chicken and evaluation of general and specific combining ability under Sudan condition. International Journal of Poultry Science 2005;4:468-471.

Moberg GP, Mench JA. The biology of animal stress basic principle and implication for animal welfare. Davis: Department of Animal Science, University of California; 2000.

National Research Council of Thailand. Ethical principles and guidelines for the use of animals. Section of research animal development, office of economic and peace creation. Thailand; 1999. 
Duangjinda M, Tunim S,

Duangdaen C, Boonkum W
Patra BN, Bais RKS, Prasad RB, Singh BP. Performance of naked neck versus normally feathered colored broilers for growth, carcass traits and blood biochemical parameters in tropical climate. Asian-Australia Journal of Animal Science 2002;15:1776-1783.

Puvadolpirod S, Thaxton JP. Model of physiological stress in chickens: 1. Response parameters. Poultry Science 2000;79:363-369.

Sharifi AR, Horst $P$, Simianer $H$.The effect of frizzle gene and dwarf gene on reproductive performance of broiler breeder dams under high and normal ambient temperatures. Poultry Science 2010;89:2356-2369.

Simaraks S, Chinrasri O, Aengwanich W. Hematological, electrolyte and serum biochemical values of the Thai indigenous chickens (Gallus domesticus) in northeastern Thailand. Songklanakarin Journal of Science and Technology 2004;26:425-430.

Tirawattanawanich C, Chantakru S, Nimitsantiwong W, Tongyai S. The effects of tropical environmental conditions on the stress and immune responses of commercial broilers, Thai indigenous chickens, and crossbred chickens. The Journal of Applied Poultry Research 2011;20:409-420.
Hsp70 Genotypes and Heat Tolerance of Commercial and Native Chickens Reared in Hot and Humid Conditions

Tunim S, Duangjinda M, Katavatin S. Study of HSP 70 gene polymorphism in various strains of Thai indigenous Chickens. KhonKaen Agriculture journal 2010; 38 Suppl:71-75.

Yu J, Bao E. Effect of acute heat stress on heat shock protein 70 and its corresponding mRNA expression in the heart, liver, and kidney of broilers. Asian-Australia Journal of Animal Science 2008;21:11161126 .

Zulkiflil, Che Norma MT, Israf DA, Omar AR. The effect of early age feed restriction on subsequent response to high environmental temperatures in female broiler chickens. Poultry Science 2000a;79:1401-1407.

Zulkiflil, Abdullah N, Azrin NM, Ho YW. Growth performance and immune response of two commercial broiler strains fed diets containing Lactobacillus cultures and oxytetracycline under heat stress conditions. British Poultry Science 2000b;41:593-597. 
